\begin{tabular}{|c|c|c|}
\hline$\overbrace{\text { JOURAL }}^{\circ}: \prod_{0}$ & IURAL SCIENCE TEACHING & $\begin{array}{l}\text { Thabiea : Journal of Natural Science Teaching } \\
\text { Vol. 3(2), pp. 141-150, } 2020 \\
\text { Available online at } \\
\text { http://journal.iainkudus.ac.id/index.php/Thabiea } \\
\text { p-issn: 2580-8474, e-issn: } 2655-898 \mathrm{X}\end{array}$ \\
\hline
\end{tabular}

\title{
The Effectiveness of Greenpreneurship Course for Students' Communication Ability and Entrepreneurial Interest
}

\author{
Mohammad Agus Prayitno $^{1^{*}}$, Ulfa Lutfianasari ${ }^{2}$, Deni Ebit Nugroho ${ }^{3}$ \\ UIN Walisongo Semarang, Jl. Prof. Dr Hamka, Semarang, 50181, Indonesia \\ Correspondence: mohammadagus@walisongo.ac.id*
}

\begin{tabular}{ll}
\hline Abstract \\
\hline Keywords: & Very tight work competition results in many unemployed people because of the \\
Greenpreneurship & imbalance between the number of jobs and the number of graduates. For this reason, \\
Communication skills & universities prepare lectures that can equip their students in entrepreneurship. One of \\
Entrepreneur & them is greenpreneursip lectures. This study aims to determine the effectiveness of \\
& learning greenpreneuron communication skills and student entrepreneurial interests. \\
& The research design used was the pre-experimental design one-group pretest-posttest \\
design. The sampling technique is done by purposive sampling. The data collection \\
method used in this study is the questionnaire method. Data collection instruments \\
included 20 items of entrepreneurial interest questionnaires and 18 items of \\
communication skills questionnaire used to determine changes in communication skills \\
and entrepreneurial interests before and after the lecture. The results were obtained \\
by the p-value of entrepreneurial interest>0.05, which is equal to 0.475. the p-value \\
of communication skills <0.05, which is equal to 0.049. The conclusion in this study is \\
the greenpreneurship course does not affect student entrepreneurial interest, but has \\
the effectiveness of studentcommunication skills.
\end{tabular}

To cite this article:

Prayitno, M. A., Lutfianasari, U. Nugroho, D. E. (2020). The Effectiveness of Greenpreneurship Course for Students' Communication Ability and Entrepreneurial Interest. Thabiea : Journal of Natural Science Teaching, Vol 3(2), 141-150.

\section{Introduction}

Education is a systematization of the process of gaining experience so that it becomes knowledge. Philosophically education is also defined as the process of acquiring learning experiences that are useful for someone in their lives. The learning experience is expected to develop one's potential and can solve real-life problems in daily life (Khoiri \& Hindarto, 2011). The most common life problem today is the problem of unemployment. Very tight job competition results in many unemployed people because of the imbalance between the number of jobs and the number of graduates. To that end, improving the quality of labor is a preparation that must be done so that Indonesia does not experience losses in the future (Devi, 2017).

Not all graduates of undergraduate programs work according to their educational qualifications. To overcome these problems, universities try to make a breakthrough to equip their students to have life skills. One of the efforts made by the chemistry education study program is the presence of Greenpreneurship courses. Greenpreneurship courses are projectbased courses. Project-based learning is one of the learning models that can develop student communication skills (Lestari et al., 2016). 
Greenpreneurship courses aim to equip students to have entrepreneurial skills after graduation. With the Greenpreneurship course, students are expected to have an alternative provision in addition to the main provision of being an educator. Greenpreneurship is expected to improve students' social life skills, especially communication skills. Communication ability is the ability of a person to convey or send a message to the recipient of the message (Cangara, 2007). Therefore, for communication to run well and smoothly and provide benefits both to the party delivering the message and to the recipient of the message, it is necessary to have communication skills. Communication skills can be seen through the communication indicator. Several indicators of communication (Hutagalung, 2007), including a) looking at the other person, b) a clear audible voice when expressing opinions, c) pleasant facial expressions (respecting the explanation of the other person), d) good grammar, and e) the conversation is easy to understand, concise, and clear. Communication can be done verbally and in writing. In Greenprenurship learning, especially when marketing products, communication is done verbally. Five indicators analyzing verbal communication skills (Oktaviani \& Hidayat, 2015), namely the ability to express opinions, listen, communicate results, ask questions, and answer.

Groups indicators of communication skills on listening skills and oral skills (Wasono, 2019). Indicators of listening skills include: listening to the explanations of others, paying close attention to the explanations of others, respecting the explanations of others, not interrupting when others talk, paying attention to the instructions of the other person. Oral skills indicators consist of: being able to politely express opinions of others, asking others politely, answering other people's questions well, presenting material to others well, and delivering the results of reports systematically and clearly.

In addition to improving students' communication skills, Greenpreneurship courses are also expected to motivate students to be able to increase their entrepreneurial interest. With the increased interest in student entrepreneurship, it is hoped that they will not be confused about finding work after graduation. Entrepreneurship is the ability to create, organize, and run your own business. Entrepreneurial interest is one's interest in creating a business with the courage to take risks which then organizes, organizes, and develops the businesses that it creates (Amalia et al., 2015; Littunen, 2000).

Entrepreneurial characteristics can be seen from various aspects of personality, such as the soul, character, attitude, and behavior of a person. Entrepreneurial characteristics that can be grown in prospective teachers include confidence, task and results-oriented, risk-takers, human-oriented, originality, future-oriented, honest and diligent, and able to see opportunities (Anoraga, 2011; Chell, 2013; Suryana, 2013; Wiyani, 2012).

Variables and indicators to measure entrepreneurial interest according (Bhandari, 2006) are: a) self-esteem, has several indicators, namely: more valued if you have your own business, more confident if you have your own business, more comfortable talking with others if you have a business that can be proud of; b) personal challenges, measured by indicators, as follows: want to try new things, like something that makes, more advanced, do something that other people can do; c) the desire to be a boss, the indicators are as follows: desire, owning your own business, free will to manage your own business, wanting to be able to develop your own business; d) innovation, has indicators that are happy things that are creative, the desire to make something different from others, happy to experiment; e) 
leadership, the indicators are: happy to talk with people, want to be a leader in a team, desires stand out from others, others; f) flexibility, has several indicators, namely: happy with work that is not binding, does not like things that are regular, do not like being bound to something; and g) profit, the indicators are: Desire to be free to run your own business finances, desire to feel wealth over your own business desire to develop their own business.

Steinhoff and Burgess said that an entrepreneur must have several skills (Suryana, 2013): have the confidence to work independently, work hard, and understand risk as part of efforts to achieve success, have organizational skills, can set goals, are results-oriented, and has responsibility for the results, good or bad; Creative and always looking for gaps for creativity; Liking challenges and getting personal satisfaction when successfully achieving his ideas. The indicators of entrepreneurship carried out in this study are limited to indicators of variables of self-esteem and self-confidence, personal challenges, innovation, and futureoriented.

Previous studies have shown that entrepreneurial learning in chemistry learning provides positive results, including being able to increase soft skills and student entrepreneurial interest (Asmorowati, 2009; Prayitno, et.al., 2016; Sumarti \& ono, 2014) increasing the ability of life skills, learning motivation, and student learning outcomes (Kusuma \& Kurniati, 2009; Prayitno, et.al., 2017), increasing entrepreneurial attitudes, creativity, and understanding of chemical concepts (Susianna, 2011), increasing the ability student cooperation and communication (Paristiowati et al., 2015), and enhance students' positive attitudes towards chemistry lessons and student entrepreneurial interests (Rahmawanna et al., 2016).

The formulation of the problem in this study is whether greenpreneurship learning is effective in communication skills and student entrepreneurial interests. The purpose of this problem is to determine the effectiveness of greenpreneur learning on communication skills and student entrepreneurial interests. Based on the description above, this study hypothesizes that there are differences in communication skills and student entrepreneurial interests before and after attending Greenpreneurship lectures.

\section{Method}

This research was conducted with a pre-experimental design method with a one-group pretest-posttest design model, which is a research design that gives treatment to the experimental group without being compared with the control group. The effect of the treatment given can be seen from the difference in the pretest and posttest. This research was conducted in three stages, namely: (1) giving initial tests before Greenpreneurship lectures, (2) conducting greenpreneurship lectures to product sales during Car Free Day (CFD) in Semarang, and (3) giving final tests after Greenpreneurship lectures.

The subjects of this study were Chemistry Education students of UIN Walisongo who took Greenpreneurship courses. The sampling technique is done by purposive sampling. The data collection method used in this study is the questionnaire method. The data collection instrument in this study was a questionnaire on communication skills and entrepreneurial interests. The communication skills questionnaire was developed based on the communication skills indicator according to Wasono (2019). Meanwhile, the entrepreneurial interest questionnaire was developed based on the indicators of entrepreneurial interest according to 
Suryana (2013). The communication skills questionnaire was used to determine changes in student communication skills, while the entrepreneurial interest questionnaire was used to determine student interests before and after taking greenpreneurship lectures. Data processing was continued with statistical tests in the form of normality tests to find out whether the data before and after learning were normally distributed or not by the Kolmogorov-Smirnov test. Then the hypothesis test was performed with the Wilcoxon test through SPSS version 16 software with a significance level of 0.05 , and the $\mathrm{N}$-gain test.

\section{Results and Discussion}

Greenpreneurship is one of the courses held by the chemistry education study program of UIN Walisongo Semarang. This course aims to provide students with life skills after graduation. By providing life skills that are inserted into a course, it is hoped that graduates of the chemistry education study program can see existing business opportunities, excel in work, and are recognized and accepted by the community so that they do not contribute to unemployment in Indonesia.

Life skills are abilities that everyone must have to face and solve various problems faced in everyday life. Life skills are not only skills for work or vocational skills, but include a broader understanding that includes the various abilities needed by a person to face various problems in life so that they can face life's problems naturally, without being pressured, and able to seek and find solutions. to the problems faced in achieving success and happiness in life in society.

Several types of life skills include communication skills. Communication skills consist of two parts, namely verbal and nonverbal. Verbal communication includes listening, speaking, and reading and writing skills. Non-verbal communication includes understanding expressions, body language, and appearance or demonstration. Thus, communication skills include listening, speaking, and writing opinions/ideas skills.

Meanwhile, the ability to work together includes the ability to be a pleasant co-worker and an empathetic leader. As a pleasant friend, one must be able to build a conducive climate for socializing, including appreciating others positively, building relationships with others, and an open attitude. Leadership includes aspects of responsibility, outreach, persistence, courage, being able to influence, and direct others.

Communication skills can be done both orally and in writing. As a social being who lives in the community where he lives and where he works, a person really needs communication skills both orally and in writing. In reality, oral communication is not easy. Often people do not accept the opinions of the interlocutor, not because of the content or ideas but because of the way they are conveyed that is not comfortable.

In this case, the ability to choose words and how to convey it is needed so that it is easily understood by the interlocutor. Because oral communication is very important, it needs to be developed from an early age to students. Communication skills can be done both orally and in writing. As social beings who live in the community where they live and work, students really need communication skills both orally and in writing. In reality, oral communication is not easy. Often people do not accept the opinions of the interlocutor, not because of the content or ideas but because of the way they are conveyed that is not comfortable. In this case, the ability to choose words and how to convey it is needed so that it 
is easily understood by the interlocutor. Because oral communication is very important, it needs to be developed from an early age to students. Another case with communication 14 in writing. In this case, skills are needed how to convey a message in writing with a choice of sentences, words, grammar, and other rules so that it is easily understood by other people or readers.

Also, life skills in their various writings refer to the various abilities needed by a person to add to life successfully, happily, and with dignity in society. Depdiknas (2002) states that life skills are skills that a person has to be brave enough to face life and life problems naturally without feeling depressed, then proactively and creatively seek and find solutions so that in the end they are able to overcome the problems they face. Meanwhile, Satori (2002) states that life skills are the various abilities that a person needs to lead a successful, happy, and dignified life in society.

These life skills can be seen in the four lifelong learning concepts proposed by UNESCO, namely: 1. Learning to know, Learning to know means learning oriented towards logical and rational knowledge, so that students dare to say opinions and be critical and have high enthusiasm for learning. The skills to ask questions and dare to express opinions need to be developed during the learning process. The learning given should be able to provide awareness to students from the community so that they are willing and able to learn. The use of the material in the form of knowledge is actually the simplest stage according to the opinion expressed by Benyamin Blom with his Cognitive Behavior Taxonomy. 2. Learning to do, Learning to do (learning to live), the aspect to be achieved is the skills of students in solving daily problems. Thus learning is directed at developing problem-solving abilities. The learning material chosen should be able to provide alternatives to students because this learning concept is not only harmful to know and understand the material, but students should be able to do something useful in life. This is in accordance with John Dewey's concept with Learning by Doing, it should be a strategy in which learning is carried out. In the end, achieving the target of a lesson can do something.

Learning to be someone. Learning to be, this vision becomes very important because learning should be oriented towards developing students to become independent individuals, having self-esteem. The learning given should be able to provide motivation to live in the present era and have a life orientation for the future so that students have the ability to be themselves in terms of self-actualization. This is a basic human need that has the highestranking to help and shape someone to be themselves through the learning process. 4. Learning to live together Learning to live together, here learning is directed at forming students who have the awareness that they live together in a global world with many people with various languages and ethnic backgrounds, religions, and diverse cultures. In this matter, the cultivation of values regarding human tolerance, the environment, tolerance, peace is the main aspects that must be internalized in the awareness of students.

Learning given to students is not only given in the form of skills on their own, but students are also provided with skills to live next door, in society, as a nation and as a state. If learning is successful, it is basically marked by the meaning of one's life in the future. Where life is not only for itself but also very meaningful for the community and the environment in which they live. So that the success of the learning process achieved by students is obtained through competition with others. So that in everyday life they are able to walk together. The 
four visions have changed the learning orientation so that it is not oriented towards academic values which are only fulfilling the cognitive aspects but also oriented to how a student can learn from the environment, from experience, and the success of others, as well as from the environment so that attitudes creative and imaginative thinking can flourish. Learning is not only directed at developing skills to live with other people, in society, as a nation, and living in international relations in the spirit of equality and teachings. The four pillars of learning cannot be seen as separate things or stand-alone because they are a continuum line in the process of achieving them. However, the four are hierarchical where the abilities below are a prerequisite for the attainment of higher abilities. The last and highest abilities are the accumulation of the abilities under him. Learning to know is a prerequisite for independent study, and independent learning is a prerequisite for collaboration. Knowing, being able to do, independently, and the ability to work together is unity and prerequisites for someone to be able to solve problems (problem-solving) and at the same time as capital to improve the quality of their life. The four pillars are knowledge, skills, independence, and the ability to adapt to the environment and be able to work together. These four pillars must be owned by every educational institution, both formal and non-formal education (Hidayanto, 2002). The development of life skills education which is based on these four concepts will have a positive impact on reducing unemployment and poverty. Satori (2002) explains that life skills have a broader meaning than employability skills and vocational skills. Life skills are skills for life. The meaning of life here is not merely having a kind of ability (vocational job), but it must have the basic supporting abilities functionally such as reading, writing, counting. Formulating and solving problems, managing resources, working in teams or groups, continuing to learn at work, using technology, and so on.

Life skills can be divided into two main types: 1. Generic life skills which include personal skills and social skills. Personal skills include skills in self-awareness or selfunderstanding (self-awareness) and thinking skills. Meanwhile, social skills include communication skills and collaboration skills. 2. Specific life skills, namely skills to deal with certain jobs or circumstances, which include: intellectual or academic skills and vocational skills. Life skills contain strengths and weaknesses or a combination of both (Depdiknas, 2002). The strengths and weaknesses of Life Skills lie in whether or not these Life Skills can help humans maintain, maintain, and develop potential according to their talents and interests.

Life skills-oriented learning has a broad scope, refers to the development of a wide range of skills needed by students to lead real-life society with success, happiness, and dignity. These life skills include the ability to communicate effectively, the ability to develop cooperation, play a role as a member of society and as a responsible citizen, have readiness and skills to work, and have character and ethics in the world of work. In line with that, learning with life skills orientation should follow the following principles: 1. National socioreligious ethics based on Pancasila values can be integrated 2. Learning uses the principles of learning to know, learning to do, learning to be, and learning to live. together and learning to cooperate 3. The development of regional potential can be reflected in the provision of education 4. Determination of community-based management collaboration of all related elements in society 5. The paradigm of learning for life and school for work can be the basis for educational activities so that they have a link with the world of work 6. The implementation of education must always direct students so that: a) Helping them to lead a 
healthy and quality life b) Gaining broader knowledge and insight, and c) Having access to be able to meet their standard of living properly (Depdiknas, 2002).

The research data both pretest and posttest before the effectiveness test is done, first the initial data is carried out, namely the data normality test. Based on the results of the normality test data it is known that the data are normally distributed, with a significance level of $>0.05$, the results obtained are 0.941 for pretest and 0.872 for the posttest. Furthermore, the data were analyzed using the t-test (paired-sample t-test). Based on the analysis using the $t$ test, a p-value of 0.49 was obtained, with the criterion $\mathrm{p}$ value $<0.05$. It can be said that Greenpreneurship learning in general can improve student communication skills. The results of communication skills research for each indicator have increased. The improvement of communication skills in each indicator can be seen in Figure 1.

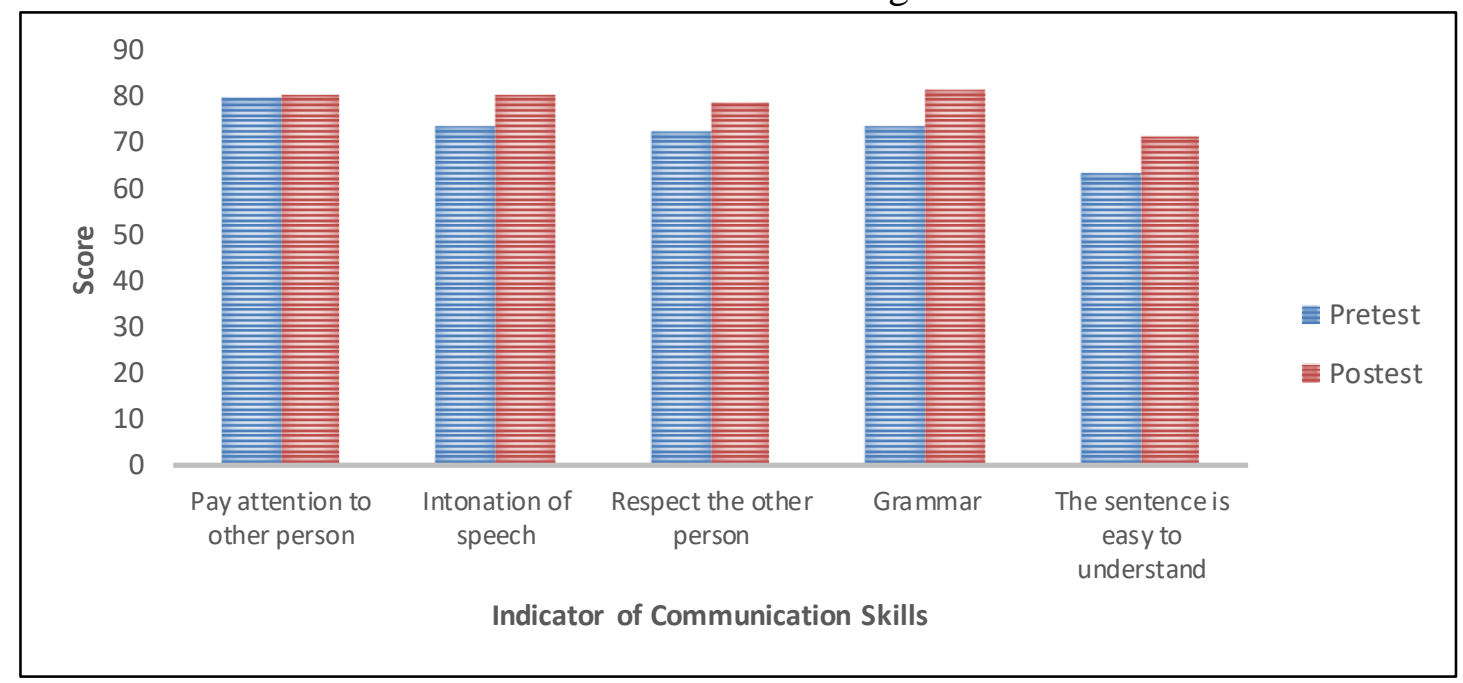

Figure 1. Communication Capability Indicator

The graph above shows that there is a change in student communication skills before and after greenpreneuship lectures. The category of changes in students 'communication skills in general before greenpreneurship lecture was in a good category, while after the lecture the students' communication skills were in a very good category. Student communication skills that have improved after attending Greenpreneurship lectures are in line with research conducted. Entrepreneurial communication skills have a positive influence on the performance of various small businesses (Rakib, 2010). Greenpreneurship courses encourage students to practice communication before they market products that have been made to the community. By practicing communicating well, it will attract someone's sympathy to buy the product it offers. The ability of human relations is one of the skills that determine performance. Besides through Greenpreneurship learning, increased communication skills can be influenced by several other factors, such as differences in intelligence, nature, environment, physical, and organ of speech (Desmita, 2011).

Like data on communication skills, entrepreneurial interest data are tested for data normality before the t-test. Based on the results of the normality test, it is known that the data is normally distributed, with a significance level of $>0.05$, which is 0.819 for pretest and 0.729 for the posttest. Furthermore, the data were analyzed using the t-test (paired-sample ttest) obtained p-value $>0.05$, namely 0.475 . This shows that there is no difference between 
student interests before and after entrepreneurial learning. Changes in entrepreneurial interest in each indicator did not experience a significant change, as shown in Figure 2.

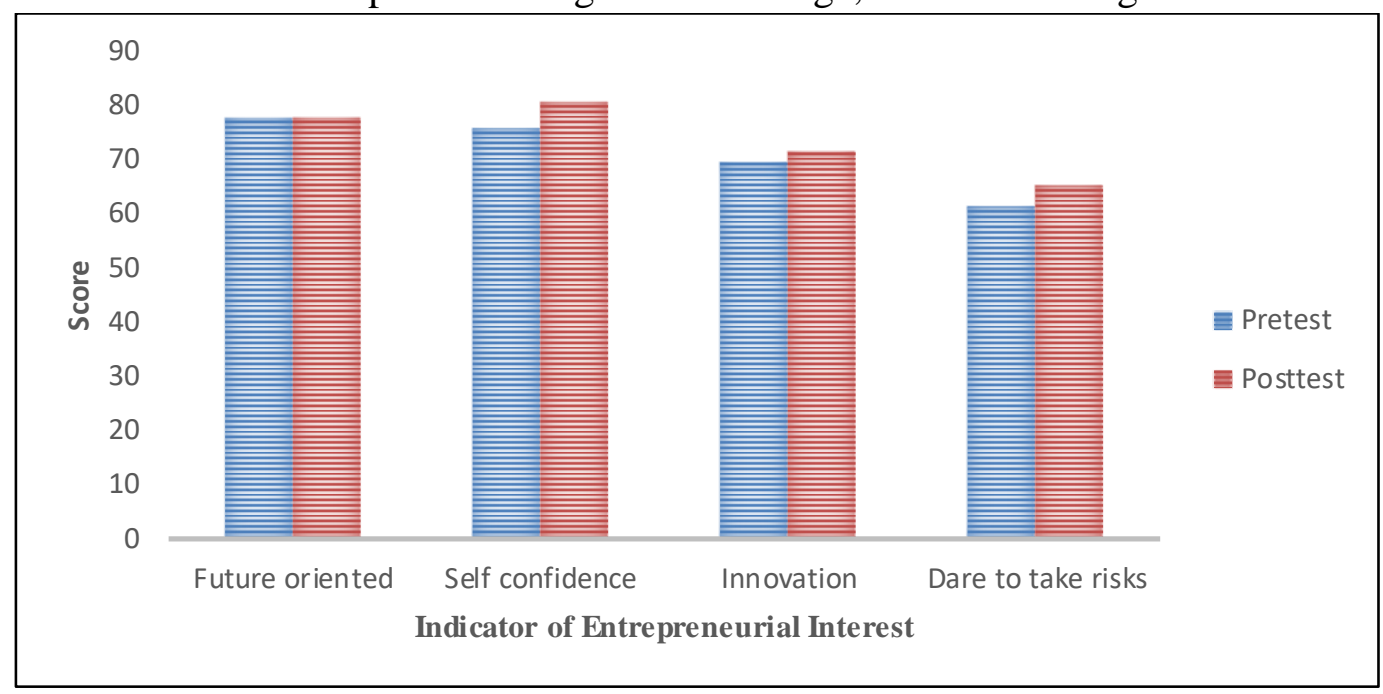

Figure 2. Changes in student entrepreneurial interest in each indicator

The family environment influences interest in entrepreneurship. The more conducive the surrounding family environment will increasingly encourage someone to become an entrepreneur. If the family environment is supportive then a person will be even more motivated to become an entrepreneur than if he does not have the support of the family environment (Suhartini, Rahardjo, 2011). The family environment with all the conditions in it which include the background of family members, family traditions and the way parents educate, will be able to support, guide, and encourage someone especially students for their future lives (Komsi, 2013).

In addition to the figure of parents who work as entrepreneurs, the figure of friends who work as entrepreneurs also influences the interest in entrepreneurship. Friends who succeed in carrying out the profession as an entrepreneur will have a positive influence to start entrepreneurship because there is a belief that he is also able to succeed like his friend. In addition to the figures of parents and friends who work as entrepreneurs, the entrepreneurs who are known can also influence the interests of student entrepreneurship (Kadarsih, 2013).

Although entrepreneurial interest has not changed, based on research $83.33 \%$ of students want to do entrepreneurship after getting entrepreneurial lectures, $16.67 \%$ of students do not want to be an entrepreneur with the reason they are still confused in determining entrepreneurship. Based on this, lecturers should encourage or show some types of chemical entrepreneurship that can be developed by students, such as the breeding of acetobacter bacteria, making yogurt, various tempe innovations, and so forth. This is to attract students to think innovatively in developing a product.

\section{Conclusion}

Based on the results of the research and discussion above, it can be revealed that Greenpreneursip courses have a positive impact on students' communication skills. In general, students' communication skills after participating in greenpreneurship learning are in the very good category. Meanwhile, students' entrepreneurial interest after learning greenpreneusip is 
in a good category. Greenpreneurship is a course that aims to develop student life skills. For this reason, in the implementation of greenpreneurship lectures, students are given the flexibility to develop their skills by making activities effective outside campuses, such as visits to home industries or places that can motivate students to become entrepreneurs. In the implementation of Greenpreneurship lectures, it should be inserted by inviting guest lecturers who have experience in entrepreneurship, especially Chemistry entrepreneurs, so that students are motivated to become entrepreneurs as the guest lecturers have experienced.

\section{References}

Amalia, H., Ayuningtias, \& Ekawati, S. (2015). Faktor-Faktor yang Mempengaruhi Minat Berwirausaha pada Mahasiswa Fakultas Ekonomi Universitas Tarumanegara. Jurnal Ekonomi.

Anoraga, P. (2011). Pengantar Bisnis: Pengelolaan Bisnis dalam Era Globalisasi. Rineka Cipta.

Asmorowati, D. S. (2009). Pembelajaran Kimia Menggunakan Kolaborasi Konstruktif Dan Inkuiri Berorientasi Chemo-Entrepreneurship. Jurnal Inovasi Pendidikan Kimia, 3(2), 476-483.

Bhandari, N. C. (2006). Intention for Entrepreneurship among Students in India. The Journal of Entrepreneurship. https://doi.org/10.1177/097135570601500204

Cangara, H. (2007). Pengantar Ilmu Komunikasi. PT. Raja Grafindo Persada.

Chell, E. (2013). Review of skill and the entrepreneurial process. International Journal of Entrepreneurial Behaviour \& Research. https://doi.org/10.1108/13552551311299233

Depdiknas. (2002). Pendidikan Berorientasi Kecakapan Hidup (Life Skill) melalui Pendekatan Broad-Based Education. Departemen Pendidikan Nasional.

Desmita. (2011). Psikologi Perkembangan Peserta Didik. Remaja Rosda Karya.

Devi, N. W. K. (2017). Rendahnya Penyerapan Tenaga Kerja di Indonesia Sebuah Tinjauan Perspektif Hubungan Industrial. Jurnal Managemen Dan Bisnis Equilibrium Point, 1(1), 133-140.

Hidayanto, D. N. (2002). Learning Skills Based on Learning Skills. Journal of Education and Culture.

Hutagalung, I. (2007). Pengembangan Kepribadian. Indeks.

Kadarsih, R. (2013). Faktor-Faktor Yang Memengaruhi Minat Berwirausaha Pada Mahasiswa Program Studi Pendidikan Ekonomi (FKIP UNS). Universitas Sebelas Maret.

Khoiri, N., \& Hindarto, N. (2011). Pengembangan Perangkat Pembelajaran Fisika Berbasis Life Skill Untuk Meningkatkan Minat Kewirausahaan Siswa. Jurnal Pendidikan Fisika Indonesia, 7(2), 84-88. https://doi.org/10.15294/jpfi.v7i2.1077

Komsi, K. (2013). Analisis Pengaruh Faktor Eksternal dan Internal terhadap Minat Berwirausaha. Proceeding PESAT.

Kusuma, E., \& Kurniati, I. (2009). Penggunaan Pendekatan Chemo-Entrepreneurship Kemampuan Life Skill Siswa Sma. Inovasi Pendidikan Kimia, 3(1), 366-372.

Lestari, I. D., Leksono, S. M., Hodijah, S. R. N., \& Agustina, W. (2016). Pengaruh Penerapan Model Pembelajaran Berbasis Proyek (Project Based Learning) terhadap Kecakapan 
Komunikasi Siswa pada Konsep Biodiversitas. Emasains: Jurnal Edukasi Matematika Dan Sains, 5(2), 83-87.

Littunen, H. (2000). Entrepreneurship and the characteristics of the entrepreneurial personality. International Journal of Entrepreneurial Behaviour \& Research. https://doi.org/10.1108/13552550010362741

Mohammad Agus Prayitno, Nanik Wijayati, dan S. M. (2016). Pengembangan Modul Pembelajaran Kimia Bervisi Sets Berorientasi Chemo-Entrepreneurship (Cep) Pada Materi Larutan Asam Basa. Jurnal Inovasi Pendidikan Kimia, 10(1), 59-65.

Oktaviani, F., \& Hidayat, T. (2015). Profil Keterampilan Berkomunikasi Siswa SMA Menggunakan Metode Fenetik dalam Pembelajaran Klasifikasi Arthropoda. Jurnal Pengajaran Matematika Dan Ilmu Pengetahuan Alam. https://d oi.org/10.18269/jpmipa.v15i1.288

Paristiowati, M., Slamet, R., \& Sebastian, R. (2015). Chemo-entrepreneurship: Learning Approach for Improving Student's Cooperation and Communication (Case Study at Secondary School, Jakarta). Procedia - Social and Behavioral Sciences, 174, 17231730. https://doi.org/10.1016/j.sbspro.2015.01.829

Prayitno, M.A., Nanik, W., \& Sri, M. (2017). Penerapan Modul Kimia Berpendekatan Chemoentrepreneurship untuk Meningkatkan Kecakapan Hidup dan Motivasi Belajar. Journal of Innovative Science Education (JISE).

Rahmawanna, R., Adlim, A., \& Halim, A. (2016). Pengaruh Penerapan Pendekatan ChemoEntrepreneurship (CEP) Terhadap Sikap Siswa Pada Pelajaran Kimia dan Minat Berwirausaha. Jurnal Pendidikan Sains Indonesia (Indonesian Journal of Science Education).

Rakib, M. (2010). Pengaruh Model Komunikasi Wirausaha, Pembelajaran Wirausaha, dan Sikap Kewirausahaan Terhadap Kinerja Usaha Kecil. Jurnal Ilmu Pendidikan.

Satori, D. (2002). Implementasi Life Skill dalam Konteks Pendidikan di Sekolah. Jurnal Pendidikan Dan Kebudayaan, 34(8).

Suhartini, Rahardjo, dan T. S. (2011). Analisis Faktor-faktor Yang Mempengaruhi Motif Belanja Secara Online Di Komunitas Kaskus Semarang. Universitas Diponegoro.

Sumarti, S. S., \& ono, H. (2014). The Training Management of Designing Life Skill and ChemoEntrepreneurship Based Learning to Chemistry Teachers of Senior High School in Semarang. IOSR Journal of Research \& Method in Education (IOSRJRME). https://doi.org/10.9790/7388-04146066

Suryana. (2013). Kiat dan Proses Menuju Sukses. Salemba Empat.

Susianna, N. (2011). The Chemistry Teaching Program for Developing the Senior High School Students' Entrepreneurial Attitudes. Online Submission.

Wasono. (2019). Pengelolaan Communication Skill Siswa SMK Muhammadiyah 3 Surakarta. Universitas Muhammadiyah Surakarta.

Wiyani, N. A. (2012). Teacherpreneurship: Gagasan dan Upaya Menumbuhkan Jiwa Kewirausahaan. Ar-Ruzz Media. 